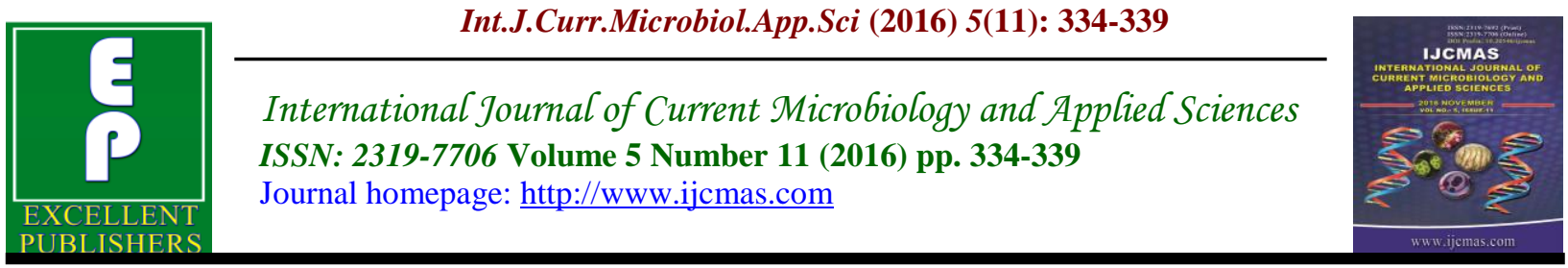

Original Research Article

http://dx.doi.org/10.20546/ijcmas.2016.511.037

\title{
Volatile Constituents and Antimicrobial Activities of Dried Rhizome of Cyperus rotundus Linn.
}

\author{
Dipali Gupta $^{1}$, Vijender Singh ${ }^{2}$ and Nipun Agrawal $^{3}$ \\ ${ }^{1}$ Department of Pharmacognosy, Department of Pharmacy, Shri Ram Murti Smarak College of \\ Engineering and Technology, 13km Bareilly-Nainital Road, Bhojipura, Bareilly, U.P., India \\ ${ }^{2}$ School of Pharmacy, Sharda University, 32, 34 Knowledge Park - III, \\ Greater Noida, U.P., India \\ ${ }^{3}$ Department of Community Medicine, Sri Ram Murti Smarak Institute of Medical Sciences, \\ $13 \mathrm{~km}$ Bareilly-Nainital Road, Bhojipura, Bareilly, U.P., India \\ *Corresponding author
}

\section{A B S T R A C T}

Keywords

Cyperus rotundus Linn., dried rhizomes, benzene, chloroform and methanolic extracts, volatile oil, sesquiterpenes, $\alpha$-Gurjunene.

\section{Article Info}

Accepted: 16 October 2016 Available Online: 10 November 2016
Cyperus rotundus Linn, a sedge of the family of Cyperaceae, is a perennial herb. Commonly known as Nagarmotha is widely distributed in the Mediterranean basin areas. This plant grows naturally in tropical, subtropical and temperate regions and is found throughout India. Volatile constituents of the dried rhizomes of Nagarmotha by GC-MS resulted in the identification of thirty four components. The oil was characterized by seven monoterpenes (11.03\%), twenty-five sesquiterepenes (78.25\%) and two unknown compounds (10.72\%). The monoterpenes present were four alcohols, two hydrocarbons and one ketone. The sesquiterpenes found were twelve hydrocarbons, eight ketones, three alcohols and one oxide and epoxide each. The monoterpene found in the highest proportion was Pinacarveol (2.64\%) and the sesquiterpene found in the highest proportion was $\alpha$ Gurjunene (21.99\%). Volatile oil of dries rhizomes of Cyperus rotundus Linn in higher concentrations showed significant antibacterial activity against the strains of Bacillus subtilis $(23 \mathrm{~mm})$ followed by Bacillus pumilis $(17 \mathrm{~mm})$ and significant antifungal activity against Candida albicans $(23 \mathrm{~mm})$. The benzene extract of rhizomes showed more potent anti-microbial activity against Bacillus subtilis and Candida albicans in comparison to chloroform and methanolic ectracts.

\section{Introduction}

Cyperus rotundus Linn, a sedge of the family of Cyperaceae, is a perennial herb. Commonly known as Nagarmotha is widely distributed in the Mediterranean basin areas. This Plant, which grows naturally in tropical, subtropical and temperate regions (Boulos and El-Hadidi, 1984). About 60 different species of Cyperaceae occur in India of which Cyperus rotundus Linn. is important for its medicinal uses. This plant is found throughout India upto an elevation of 1800m form Kashmir to Simla, Garhwal \& Khasia hills, throughout the plains of almost all the states \& ascending the mountains of 
the Central table-land from Mount Abu \& Pune to the Nilgiri hills (Sharma et al., 2002). Cyperus rotundus rhizomes \& leaves on hydrodistillation yield a volatile oil which possess anti-microbial and antiinflammatroy properties. 27 compounds from the essential oil including copadiene, epoxyguaione, rotundone, eugenol were indentified cyperene, selinene, cyperenone and cyperone were reported as major constituents of essential oil from rhizomes of C. rotundus (Komai et al., 1977). C.rotundus contains an essential oil that provides for the characteristic odour and taste of the herb, comprised mostly sesquiterpene hydrocarbons, epoxides, ketones, monoterpenes and aliphatic alcohols. Sesquiterpenes include selinene, isocurcumenol, nootkatone, aristolone, isorotundene, cypera-2,4(15)-diene, and norrotundene, as well as the sesquiterpene alkaloids rotundines A-C. Other constituents include the ketone cyperadione, and the monoterpenes cineole, camphene and limonene. C.rotundus has also been shown to contain miscellaneous triterpenes including oleanolic acid and sitosterol, as well as flavonoids, sugars and minerals

The rhizomes of $C$. rotundus have been used in ancient medicine in India for fever, dysentery, pruritis, pain, vomiting and various blood disorders (Kirtikar et al., 1944). It is also a home remedy for indigestion disorders of stomach \& irritation of bowel (Joshi SG, 2000). The plant possesses anti-malarial (Thebtaranonth et al., 1995), anti-diabetic (Bowden et al., 1999), \& insecticidal properties (Morimato et al., 1999)

\section{Experimental}

\section{Plant material}

The plant material was collected from the local market from M/s Gattumal and Sons,
Alamgiri Ganj, Bareilly (U.P.). Identification and authentication was done by $\mathrm{Dr}$ Alok Kumar Khare, Associate Professor, Department of Botany, Bareilly College, Bareilly (U.P.) reference number HBCB/588 dated $6^{\text {th }}$ Jan 2015. A voucher specimen was kept in the herbarium of the Department of Botany, Bareilly College, Bareilly (U.P.).

\section{Isolation}

The dried rhizomes (1 kg) were hydrodistilled for 3 hours according to the method recommend in the British Pharmacopoeia 2003. The yield of volatile oil obtained was $0.6 \% \mathrm{v} / \mathrm{w}$. The amber coloured volatile oil was collected in the graduated tube. The collected volatile oil was dried over anhydrous sodium sulphate and stored in the dark.

\section{GC Analysis}

Analytical GC was carried out on a Varian 3300 GC fitted with a silicone DB-1 capillary column $(30 \mathrm{~m} \times 0.25 \mathrm{~mm})$, film thickness $0.25 \mu \mathrm{m}$, carrier gas Nitrogen, flow rate $1.5 \mathrm{ml} / \mathrm{min}$., split mode, temperature programmed $80-250{ }^{0} \mathrm{C}$ at $4{ }^{0} \mathrm{C} / \mathrm{min}$. Injector temperature and detector temperature were $250{ }^{0} \mathrm{C}$ and $300{ }^{0} \mathrm{C}$ respectively. Detector used was FID. Injection volume for all samples was $0.1 \mu$.

\section{GC-MS Analysis}

GC-MS Analysis was carried out on a QP2000 instrument at $70 \mathrm{eV}$ and $250^{\circ} \mathrm{C}$. GC column Ulbon HR-1 fused silica capillary $0.25 \mathrm{~mm} \times 50 \mathrm{~m}$ with film thickness $0.25 \mu \mathrm{m}$. The initial temperature was $100{ }^{0} \mathrm{C}$ for six minutes and then heated at a rate of $10{ }^{0} \mathrm{C}$ per min. to $250{ }^{\circ} \mathrm{C}$. Carrier gas Helium, flow rate $2 \mathrm{ml} / \mathrm{min}$., detector used was FID. 


\section{Identification of volatile constituents}

The individual compounds were identified by comparing their retention indices (RI) of the peaks on ULBON HR-1 fused silica capillary column with literature values, matching against the standard library spectra, built up using pure substances and components of known essential oils. Further identification was made by comparison of fragmentation pattern of mass spectra obtained by GC-MS analysis with those stored in the spectrometer database of NBS 54 K.L, WILEY8 libraries and also with those reported in the literature (Adams, 1995; Libey, 1991; Jennings and Shibamoo, 1980; Swigar and Silverstein, 1981; Anderson and Falcone, 1969; Ali, 2001).

Relative amounts of identical components were based on peak areas obtained without FID response factor correction. Volatile constituents were identified by comparing their Kovats indices and retention times with those of authentic standards available in the author's laboratory and with those of literature are summarized in Table 1 . The constituents were arranged in order of GLC and GC-MS elution on silicon DB-1 and ULBON HR-1 fused silica column, respectively.

\section{Antimicrobial activity}

\section{Preparation of sample}

The volatile oil $(0.1 \% \mathrm{v} / \mathrm{v}, 0.5 \% \mathrm{v} / \mathrm{v}, 1 \%$ $\mathrm{v} / \mathrm{v}$ ) and dried benzene, chloroform and methanolic extracts were dissolved in dimethyl sulfoxide (DMSO) for antimicrobial activity.

\section{Preparation of Standard Drugs Solution}

Chloramphenicol and Ketoconazole were used as standard solutions for comparison of anti-bacterial and anti-fungal studies. Both the standard drugs were taken in DMSO. The concentration of both standard drug solutions was $10 \mathrm{mg} / \mathrm{ml}$.

\section{Anti-microbial Activity}

The antimicrobial activities of volatile oil and dried alcoholic extract of dried rhizome of Cyperus rotundus were collected and the experiments were performed in Microbiology laboratory, Sri Ram Murti Smarak Institute of Medical Sciences, Bareilly, U. P. The identification of microbial strains was based on morphological, cultural and biochemical tests. The antibacterial activities of various oil concentrations and dried alcoholic extract of the dried rhizome of Cyperus rotundus were studied by the cup plate method (Pharmacopoeia of India, 1996; Macki and McCartney, 1980; Singh et al., 2008) against various microorganisms mentioned in the Table 2. Chloramphenicol and Ketoconazole were used as standard and the activity of each concentration was compared with corresponding concentration of standard drugs. The plates were incubated at $37 \pm 2{ }^{\circ} \mathrm{C}$ for antibacterial activity and 25 $\pm 2{ }^{\circ} \mathrm{C}$ for anti fungal activity, after $48 \mathrm{hrs}$ of incubation. The Petri dishes were taken out from the incubator and the anti-microbial activity of different concentrations of oil and dried alcoholic extract of dried rhizome of Cyperus rotundus were compared by measuring the diameter of the zone of inhibition. (Table 2)

\section{Result and Discussion}

The volatile components of the Cyperus rotundus Linn. are listed in table No.1. Components are arranged in order to GCelution. The oil was characterized by seven monoterpenes (11.03\%), twenty-five sesquiterepenes $(78.25 \%)$ and two unknown compounds $(10.72 \%)$. The monoterpene 
alcohols (6.54\%) present in our sample included Pinacarveol (2.64\%), Myrtenol (1.87\%), p Menth -1 en-8-ol (1.21\%), trans carveol $(0.82 \%)$. The monoterpene hydrocarbons $(2.69 \%)$ found were $\beta$ - Pinene $(1.51 \%)$ and $\alpha-$ Thujene (1.18\%). The monoterpene ketone found was Verbenone $(1.80 \%)$. The sesquiterpene hydrocarbons $(51.8 \%)$ present were $\alpha-\quad$ Gurjunene (21.99\%), Delta Guaiene (7.31\%), Valencene (5.74\%), $\alpha$ - Cubebene (4.67\%), $\beta$ - selinene $(4.12 \%)$, allo aromadendrene (1.91\%), $\beta$ - Selinene (1.69\%), $\alpha$ - humulene $(1.37 \%), \alpha$ - selinene $(1.23 \%), \beta$ - elemene $(0.71 \%)$, Eudesma - 2,4,11 - triene $(0.53 \%)$ and Oxo-alpha ylangene $(0.53 \%)$. The sesquiterpene ketones (16.08\%) included Isolongifolen $\quad-5$-one $\quad(6.41 \%)$, longiverbenone (4.62\%), Nootkatone
$(1.62 \%)$, Oxo- cyperone $(0.89 \%), \alpha-$ cyperone $(0.84 \%)$, Aristolone $(0.68 \%)$, Oplopenone $(0.57 \%)$ and Solavetivone $(0.45 \%)$. The sesquiterpene alcohols (4.53\%) found in our sample were Globulol (2.23\%), Patchenol (1.39\%) and Spathulenol $(0.91 \%)$. The sesquiterpene oxide and epoxide present were Caryophyllene oxide $(5.13 \%)$ and Aromadendrene epoxide $(0.71 \%)$ respectively.

Volatile oil of dried rhizomes of Cyperus rotundus Linn in highest concentrations $(1 \% \mathrm{v} / \mathrm{v})$ showed significant antibacterial activity against the strains of Bacillus subtilis (23mm) followed by Bacillus pumilis $(17 \mathrm{~mm})$ and significant antifungal activity against Candida albicans (23mm).

Table.1 Chemical composition of volatile constituents of Cyperus rotundus Linn. rhizomes

\begin{tabular}{|c|c|c|c|c|c|c|c|}
\hline S. No. & Component & $\mathbf{R I}$ & $\%$ age & S. No. & Component & RI & $\%$ age \\
\hline 1. & $\alpha$-Thujene & 915 & 1.18 & 18. & $\alpha$ - selinene & 1490 & 1.23 \\
\hline 2. & $\beta$-Pinene & 980 & 1.51 & 19. & Spathulenol & 1552 & 0.91 \\
\hline 3. & Pinacarveol & - & 2.64 & 20. & Oplopenone & 1608 & 0.57 \\
\hline 4. & p Menth -1 en-8-ol & - & 1.21 & 21. & Caryophyllene oxide & 1615 & 5.13 \\
\hline 5. & Myrtenol & 1195 & 1.87 & 22. & Globulol & 1631 & 2.23 \\
\hline 6. & Verbenone & 1205 & 1.80 & 23. & Isolongifolen -5-one & - & 6.41 \\
\hline 7. & trans - carveol & 1202 & 0.82 & 24. & Patchenol & 1628 & 1.39 \\
\hline 8. & $\alpha$ - Cubebene & - & 4.67 & 25. & Aromadendrene epoxide & - & 0.71 \\
\hline 9. & $\beta$ - elemene & 1383 & 0.71 & 26. & $\alpha$ - cyperone & - & 0.84 \\
\hline 10. & $\alpha$ - Gurjunene & 1431 & 21.99 & 27. & longiverbenone & - & 4.62 \\
\hline 11. & $\beta$-Selinene & 1454 & 1.69 & 28. & Oxo- cyperone & -- & 0.89 \\
\hline 12. & Delta Guaiene & - & 7.31 & 29. & $\mathrm{C}_{15} \mathrm{H}_{22} \mathrm{O}$ & - & 9.14 \\
\hline 13. & $\alpha$ - humulene & 1460 & 1.37 & 30. & Oxo-alpha ylangene & 1739 & 0.53 \\
\hline 14. & Valencene & - & 5.74 & 31. & $\mathrm{C}_{15} \mathrm{H}_{22} \mathrm{O}$ & - & 1.58 \\
\hline 15. & allo aromadendrene & 1468 & 1.91 & 32. & Aristolone & 1752 & 0.68 \\
\hline 16. & Germatrene E & 1471 & 0.53 & 33. & Solavetivone & 1816 & 0.45 \\
\hline 17. & Eudesma - 2,4,11 - triene & 1476 & 4.12 & 34. & Nootkatone & 1820 & 1.62 \\
\hline
\end{tabular}

RI-Retention index

Monoterpenes $(7)=11.03 \% ;$ Hydrocarbons $(2)=2.69 \% ;$ Alcohols $(4)=6.54 \% ;$ Ketone $(1)=1.8 \%$

Sequiterpenes $(25)=\%$; Hydrocarbons $(12)=51.8 \%$; Alcohols $(3)=4.53 \%$; Ketones $(8)=16.08 \%$; Oxide $(1)=$ $5.13 \%$; Epoxide $(1)=0.71 \%$

Unknown compounds $(2)=10.72 \%$ 
Table.2 Antimicrobial activity of volatile oil and different extracts of Cyperus rotundus Linn. of dried rhizome

\begin{tabular}{|c|c|c|c|c|c|c|c|c|c|c|c|c|c|c|c|}
\hline \multirow{3}{*}{$\begin{array}{l}\text { S.No } \\
\text {. }\end{array}$} & \multirow{3}{*}{ Test organism } & \multicolumn{12}{|c|}{ Zone of Inhibition (in mm) ${ }^{a}$} & \multirow{3}{*}{$\begin{array}{c}\begin{array}{c}\text { Erythromyci } \\
\text { n estolate }\end{array} \\
(\mathbf{m c g} / \mathrm{ml}) \\
50\end{array}$} & \multirow{3}{*}{$\begin{array}{c}\begin{array}{c}\text { Ketoonazol } \\
\text { e }\end{array} \\
\text { (mcg/ml) } \\
50\end{array}$} \\
\hline & & \multicolumn{3}{|c|}{ Conc. of Volatile Oil } & \multicolumn{3}{|c|}{$\begin{array}{c}\text { Dried benzene } \\
\text { extract }(\mathrm{mg} / \mathrm{ml})\end{array}$} & \multicolumn{3}{|c|}{$\begin{array}{c}\text { Dried } \\
\text { chloroform } \\
\text { extract } \\
(\mathbf{m g} / \mathbf{m l}) \\
\end{array}$} & \multicolumn{3}{|c|}{$\begin{array}{c}\text { Dried } \\
\text { methanolic } \\
\text { extract }(\mathrm{mg} / \mathrm{ml})\end{array}$} & & \\
\hline & & $\begin{array}{c}0.1 \\
\% \mathrm{v} / \\
\mathrm{v}\end{array}$ & $\begin{array}{c}0.5 \\
\% \mathrm{v} / \\
\mathrm{v}\end{array}$ & $\begin{array}{c}1.0 \\
\% \mathrm{v} / \\
\mathrm{v}\end{array}$ & 50 & $\begin{array}{c}10 \\
0\end{array}$ & $\begin{array}{c}15 \\
0\end{array}$ & $\begin{array}{l}5 \\
0\end{array}$ & $\begin{array}{c}10 \\
0\end{array}$ & $\begin{array}{c}15 \\
0\end{array}$ & 50 & $\begin{array}{c}10 \\
0\end{array}$ & $\begin{array}{c}15 \\
0\end{array}$ & & \\
\hline 1. & $\begin{array}{l}\text { Bacillus } \\
\text { subtilis }\end{array}$ & 17 & 19 & 23 & $\begin{array}{l}1 \\
0 \\
\end{array}$ & 14 & 17 & 9 & 12 & 15 & $\begin{array}{l}0 \\
2 \\
\end{array}$ & 05 & 08 & 29 & - \\
\hline 2. & $\begin{array}{l}\text { Bacillus } \\
\text { pumilis }\end{array}$ & 12 & 14 & 17 & 5 & 7 & 9 & 5 & 8 & 9 & $\begin{array}{l}0 \\
1\end{array}$ & 04 & 09 & 24 & - \\
\hline 3. & $\begin{array}{c}\text { Pseudomona } \\
\text { s } \\
\text { aeruginosa }\end{array}$ & 9 & 10 & 11 & 5 & 7 & 9 & 3 & 5 & 8 & $\begin{array}{l}0 \\
2\end{array}$ & 04 & 07 & 15 & - \\
\hline 4. & $\begin{array}{l}\text { Shigella } \\
\text { flexneri }\end{array}$ & 12 & 13 & 15 & 6 & 7 & 9 & 4 & 5 & 9 & $\begin{array}{l}0 \\
1\end{array}$ & 03 & 06 & 18 & - \\
\hline 5. & $\begin{array}{l}\text { Candida } \\
\text { albicans }\end{array}$ & 18 & 20 & 23 & $\begin{array}{l}1 \\
1 \\
\end{array}$ & 14 & 17 & 8 & 10 & 14 & $\begin{array}{l}0 \\
3 \\
\end{array}$ & 06 & 10 & - & 28 \\
\hline 6. & $\begin{array}{c}\text { Aspergillus } \\
\text { niger }\end{array}$ & 16 & 17 & 19 & $\begin{array}{l}1 \\
0\end{array}$ & 12 & 15 & 6 & 9 & 12 & $\begin{array}{l}0 \\
2 \\
\end{array}$ & 05 & 09 & - & 23 \\
\hline
\end{tabular}

a - an average of triplicate.

Erythromycin estolate - against bacterial strains only.

Ketoconazole - against fungal strains only.

The benzene, chloroform and methanolic extracts of rhizomes showed anti-microbial activity against Bacillus subtilis, Bacillus pumilis, Pseudomonas aeruginosa, Shigella flexneri, Aspergillus niger \& Candida albicans in comparison with Erythromycin estolate \& Ketoconazole standard antibiotics respectively.

The benzene extract showed antimicrobial activity at concentration $50 \mathrm{mg} / \mathrm{ml}$, $100 \mathrm{mg} / \mathrm{ml} \& 150 \mathrm{mg} / \mathrm{ml}$ against Bacillus subtilis $(10,14,17 \mathrm{~mm})$, Bacillus pumilis (5,7,9 mm), Pseudomonas aeruginosa (5,7,9 $\mathrm{mm})$, Shigella flexneri $(6,7,9 \mathrm{~mm})$ Aspergillus niger $(10,12,15 \mathrm{~mm}) \&$ Candida albicans $(11,14,17 \mathrm{~mm})$ in comparison with Erythromycin estolate \& Ketoconazole standard antibiotics respectively.

The chloroform extract also showed antimicrobial activity at concentration $50 \mathrm{mg} / \mathrm{ml}, 100 \mathrm{mg} / \mathrm{ml} \& 150 \mathrm{mg} / \mathrm{ml}$ against
Bacillus subtilis $\quad(9,12,15 \mathrm{~mm}), \quad$ Bacillus pumilis $\quad(5,8,9 \mathrm{~mm}), \quad$ Pseudomonas aeruginosa $(3,5,8 \mathrm{~mm})$, Shigella flexneri $(4,5,9 \mathrm{~mm})$ Aspergillus niger $(6,9,12 \mathrm{~mm})$ \& Candida albicans $(8,10,14 \mathrm{~mm})$ in comparison with Erythromycin estolate \& Ketoconazole standard antibiotics respectively.

The methanol extract showed antimicrobial activity at concentration $50 \mathrm{mg} / \mathrm{ml}$, $100 \mathrm{mg} / \mathrm{ml} \& 150 \mathrm{mg} / \mathrm{ml}$ against Bacillus subtilis $(2,5,8 \mathrm{~mm})$, Bacillus pumilis $(1,4,9$ $\mathrm{mm})$, Pseudomonas aeruginosa $(2,4,7 \mathrm{~mm})$, Shigella flexneri $(1,3,6 \mathrm{~mm})$ Aspergillus niger $(2,5,9 \mathrm{~mm})$ \& Candida albicans $(3,6,10 \mathrm{~mm})$ in comparison with Erythromycin estolate \& Ketoconazole standard antibiotics respectively.

\section{Acknowledgements}

The authors thankful to Sh. Dev Murti Jee, Chairman, SRMS Trust and Sh. Aditya 
Murti Jee, Director Administration, SRMS IMS, Bareilly, U. P. for their support and positive attitude towards research along with Dr. Robin Singh, Senior Scientist, Indian Pharmacopoeia Commission, Ghaziabad, U. P. for the spectral analysis.

\section{References}

Adams, R.P. 1995. 'Identification of Essential Oil components by Gas Chromatography/Mass spectrometry', Allured publications Corp. Curol Steane, IL.

Ali, M. 2001. 'Techniques in Terpenoid Identification', Birla Publishers, New Delhi.

Anderson, N.H. and Falcone, M.S. 1969. 'The Identification of sesquiterpenes hydrocarbons from GLC retention data', $J$. Chromatography, 44, pp 52- 59.

Anonymous. 1999. 'The Ayurvedic Pharmacopoeia of India', Vol III part-I, First edition, published by The Controller of Publications, Civil lines, Delhi on behalf of department of Indian system of Medicine and Homoeopathy, Ministry of Health and Family Welfare, Gov. of India', pp 129-130.

Anonymous. 2001. 'The Wealth of India', raw materials, Vol - III, published by NISCAIR, CSIR, New Delhi', pp 333-334.

Boulos, L., El-Hadidi, M.N. 1984. 'The Weed Flora of Egypt', The American University in Cairo Press, Cairo, pp. 58.

Jennings, W. and Shibamoo, T. 1980. 'Qualitative Analysis of Flavour and Fragrance Volatiles by Capillary Gas Chromatography', Academic Press, New York.
Joshi, S.G. 2000. 'Medicinal plants Calcutta' Oxford and IBH Publishing, pp 170.

Kirtikar, K.R., Basu, B.D. 1944. 'Indian Medicinal Plants' 4 , pp 2638.

Komai, K., Iwamura, J., Ueki, K. 1977. 'Isolation, identification and physiological activities of sesquiterpenes in purple nutsedge', Weed Res. Jpn., 22, pp14-18.

Libey, L.M. 1991. 'A paradox database for GC/MS data components of essential oil and other volatiles', J. Essent. Oils. Res., 3: pp 193-194.

Mackie, W. and McCartney, L. 1980. 'Practical Medical Microbiology', $13^{\text {th }}$ Edn. Churchill Livingstone, Edinburg, London, pp 162.

Morimoto, M., Fujii, Y., Komai, K. 1999. 'Antifeedants in Cyperaceae: coumaran and quinones from Cyperus spp.', Phytochem., 51(5), pp 605-8.

Pharmacopoeia of India. 1996. Controller of Publication, Ministry of Health and Family Welfare, Govt of India, New Delhi, Vol II, p. A-105.

Sharma, P.C., Yelne, M.B. \& Demnis, T.J. 2002. 'Database on medicinal plants used in Ayurveda', Published by Central Council for Research in Ayurveda \& Siddha, New Delhi 3, pp 400-406.

Singh Vijender. 1984. 'Phytochemical and microbiological investigations on Diospyros Montana Roxb.,' Hamdard College of Pharmacy, Hamdard Nagar, New Delhi.

Singh, V., et al. 2008. 'Volatile Constituents and Antimicrobial and Antifungal activities of Immature Green Seeds of Trachyspermum ammi Linn.', J. Essential Oil Bearing Plants, 11(1), pp 120- 123.

Swigar, A.A. and Silverstein, R.M. 1981. 'Monoterpenes', Aldrich Chem. Co., Milwakee WI.

\section{How to cite this article:}

Dipali Gupta, Vijender Singh and Nipun Agrawal. 2016. Volatile Constituents and Antimicrobial Activities of Dried Rhizome of Cyperus rotundus Linn. Int.J.Curr.Microbiol.App.Sci. 5(11): 334-339. doi: http://dx.doi.org/10.20546/ijcmas.2016.511.037 